\title{
Using offsets to mitigate environmental impacts of major projects: A stakeholder analysis
}

\begin{abstract}
Global patterns of development suggest that as more projects are initiated, business will need to find acceptable measures to conserve biodiversity. The application of environmental offsets allows firms to combine their economic interests with the environmental and society. This article presents the results of a multi-stakeholder analysis related to the design of offsets principles, policies, and regulatory processes, using a large infrastructure projects context. The results indicate that business was primarily interested in using direct offsets and other compensatory measures to acquit their environmental management obligations. In contrast, the environmental sector argued that highly principled and scientifically robust offsets program should be implemented and maintained for enduring environmental protection. Stakeholder consensus stressed the importance of offsets registers with commensurate monitoring and enforcement. Our findings provide instructive insights into the countervailing views of offsets policy stakeholders.
\end{abstract}

Keywords: biodiversity; business; development projects; environmental offsets; management; policy. 


\section{Introduction}

Projected global economic growth is set to reach 3.7\% per annum by end 2016 (IMF, 2015). Broadly, this indicates the initiating of many infrastructure projects in future years, thus placing further pressure to prioritize development over the environment (Reid, 2011). Consequently, firms will need to equitably advance development projects, having regard to the environmental consequences for the site (Jones, 2013). In addressing this balance, firms may be required to implement a package of environmental offsets (Gibbons and Lindenmayer, 2007; Kiesecker et al., 2009) that are 'the measurable conservation outcomes resulting from actions designed to compensate for significant residual adverse biodiversity impacts arising from project development after appropriate prevention and mitigation measures have been taken' (BBOP, 2012b; Bull et al., 2013; Coggan et al., 2013). As an example, a firm may undertake an ecological protection measure to offset the biodiversity impacts of projects (BBOP, 2012b). In contrast, the mitigation hierarchy outlines the alternatives to offsets as avoidance, minimisation (e.g. design electricity wiring to reduce species death, build a wildlife escape path across roads) and rehabilitation/restoration (e.g. plant trees to stabilise bare soil, stop erosion) (CSBI, 2015).

Given the growth in offsets policies, their wide use in infrastructure projects, and the contentious nature of their efficacy, it would appear sensible to examine offsets program principles, policies and lifecycle processes (Bull et al., 2013). Accordingly, in this study we address two research questions. First, having regard to offsets principles, policies, and programs, what are the barriers and opportunities associated with improving environmental offsets delivery? Studies show that environmental offsets may suffer from policy shortcomings, including deficiencies in equivalence, time lags, and faulty offsets currency determinations (McKenney and Kiesecker, 2010; Burgin, 2011; Maron et al., 2012). Hence, in this article, we seize the opportunity to examine problem areas from differing stakeholder viewpoints (Bull et al., 2013). Second, what regulatory enhancements would enable better outcomes when assessing and implementing environmental offsets? Thus, we seek to determine where the weight of stakeholder opinion is strongest and expose adjustments to regulatory processes that may result in improved 
outcomes (BBOP, 2012b; Bull et al., 2013; Alvarado-Quesada et al., 2014). In this respect, the study makes an academic and practitioner contribution in the area of environmental management.

The article will discuss the background, problems and opportunities associated with environmental offsets, including a summary of environmental impacts and offsets strategies proposed in five large infrastructure projects in Australia (comparatively advanced offsets policies) (Miller et al., 2015). Also, we outline the stakeholder analysis, data sourcing and results presentation methodology used to generate the results and discuss findings. The article will conclude with final observations of the tensions that surround offsets packages, and commend areas for policy and legislative improvement.

\subsection{Offsets Literature}

Early studies of environmental offsets were positive and asserted the importance of investing in conservation measures that addressed biodiversity and societal benefits (Hardner et al., 2000). However, there were also studies of offsets problems, such as packaging equivalence, time lagged delivery, equitable currency determinations, 'no net loss' (NNL) of biodiversity, and offsets risk (Gibbons and Lindenmayer, 2007; Hayes and Morrison-Saunders, 2007; Moilanen et al., 2009; Maron et al., 2012; Gardner et al., 2013; Curran et al., 2014), coupled with moderate offsets successes (Burgin, 2010).

As an example, Bull et al. (2013) identified several key issues associated with offsets. Quantitatively, the valuation of the impacts to be offset, and the guiding principle of NNL of biodiversity, present as problems for practitioners (Brownlie and Botha, 2009; Maron et al., 2010; BBOP, 2012a; Bull et al., 2014). In particular, the combination of complex factors (e.g. offset land area, comparable biodiversity condition) (Latimer and Hill, 2007; Norton, 2009; McKenney and Kiesecker, 2010; Sherren et al., 2012; Gardner et al., 2013) and net present value calculations (e.g. discount rates vary from 2-14\% depending on scope and risk factors) for multi-year offsets projects (Overton et al., 2013), challenges consistent and precise valuations. That said, we acknowledge that other quantification methods, such as the economic value attached to ecosystems services, may also assist offsets valuation (e.g. offsets may deliver provisioning services where benefits such as drinking water for human consumption may result; or regulating services where ecosystem processes may offer benefits such as pollination or water purification) (Blignaut et al., 2013, 2014; Costanza et al., 2014). In addition, the analyses of the 
positive relationships between humans and ecosystems reinforces the benefits of individual and societal wellbeing in spiritual, recreational, reflective and cognitive dimensions, thereby accentuating the value of offsets (Hassan et al., 2005; Hegmann and Yarranton, 2011).

In addressing NNL, dynamic changes in natural systems means that net losses and gains must be framed against fixed or variable biodiversity baselines so as to stop policy manipulation, and identify damage unable to be offset (Kiesecker et al., 2009; Ruhl and Salzman, 2011; Gardner et al., 2013; Gordon et al., 2015; Maron et al., 2015). Subsequently, experts have called for better estimation of NNL and net gain, including clarity around the scale of the loss/gain (i.e. project, landscape, region) (Brownlie and Botha, 2009; Virah-Sawmy et al., 2014). Others argued that offsets should provide additional contributions to conservation (i.e. 'additionality') (McKenney and Kiesecker, 2010; Rajvanshi et. al., 2011; Pickett et al., 2013), with other quantitative problems including the offsets program length, lags between impacts and outcomes, and offsets risk estimates (Gordon et al., 2011; Maron et al., 2012; Curran et al., 2014). Some suggest that offsets delivery risks might be lessened using longer agreements and staged contracts (Doole et al., 2014).

Qualitative problems include demonstrating package equivalence, defining the reversibility of biodiversity losses, and establishing thresholds beyond which impacts cannot be compensated (i.e. irreversible loss) (Norton, 2009; Gardner et al., 2013; Regnery et al., 2013). As an example, while offsets are meant to reverse project impacts (Morrison-Saunders and Pope, 2013), this may not occur in practice with resulting irreversible losses (Morrison-Saunders and Therivel, 2006; Bull et al., 2013). Also, the concept of equivalence has raised complex questions over proposed in-kind or out-of-kind exchanges (e.g. trading flora loss for fauna gain) (Walker et al., 2009; Bekessy et al., 2010; Burgin, 2010; Bull et al., 2013), and the relative value of direct offsets (e.g. site based environmental conservation) versus Other Compensatory Measures (OCMs) (e.g. biodiversity research funding) (Bekessy et al., 2010; Overton et al., 2013; Miller et al., 2015). Hence, these variations may see stakeholders provide differing opinions as to how these problems might be addressed.

Arguably, despite these problems, offsets have an important role to play in future sustainable developments (Dietz and Adger, 2003) with opportunities to apply offsets principles, criterion and 
indicators in policies (BBOP, 2012b); expand offsets usage (Bayon and Jenkins, 2010; AlvaradoQuesada et al., 2014; Doole et al., 2014); and, potentially increase private and public investment for environmental conservation (Kiesecker et al., 2009; Kumaraswamy and Udayakumar, 2011; Quintero and Mathur, 2011). Collectively, these directions present as potential opportunities for developing offsets policies and programs.

\subsection{Research Background}

This study is based on data collected during a public inquiry into the application of environmental offsets in project approvals granted by the Australian government under the Environment Protection and Biodiversity Conservation (EPBC) Act 1999 (Commonwealth of Australia, 2012, 2014b). Australia employs three tiers of government (e.g., federal, state/territory, and local), with the federal government regulating impacts on a specific set of environmental values (i.e. protected matters) through the EPBC Act 1999. State/territory and local governments have responsibilities for implementing environmental policies within their jurisdiction under the Intergovernmental Agreement on the Environment (1992) (Commonwealth of Australia, 1992). The federal policy and offsets assessment guide were launched in 2012 and include operating principles, development guidelines and a computational assessment guide (quantity, quality, risk). A policy history and review can be found in Miller et al (2015). The public inquiry provided an excellent site for crowdsourced data collection with a full and searching examination of federal offsets programs.

During the inquiry, ninety-seven individuals and organizations (business, government and nongovernment) offered a wide range of written discourse on the federal government's implementation of environmental offsets. In particular, the government encouraged project shareholders and stakeholders to provide statements in the context of five major infrastructure projects that impact biodiversity and the broader environment (see Fig. S1). As of early 2014, these five projects account for around 31,500 hectares of cleared land and disturbed habitats, with proposed offsets exceeding 75,500 hectares of habitat conservation. Accordingly, the data analysis draws together broader policy and program issues, with context-specific statements and discussion related to major projects. 


\section{Methods and Materials}

The study used a structured content analysis (Gordon et al., 2012; Miles et al., 2014) of 97 stakeholders' submissions to the government inquiry. A five node data structure that reflected the inquiry's logical flow of offsets principles and policy setting through to the reporting of approved offsets programs outcomes and results was established (1. Offsets Principles and Policy; 2. Offsets Proposal - Development and Submission; 3. Offsets Proposal - Assessment and Approval; 4. Approved offsets - Monitoring and Evaluation; 5. Approved offsets - Outcomes and Results) (Commonwealth of Australia, 2014b) and enabled statements to be tightly and precisely coded to each node (Denzin and Lincoln, 2011). Statements were two-stage coded and registered on a five-part research database. In stage one, all statements were read, interpreted and open coded within each node (e.g. Sub. 5, page 5: Read: 'Offset activities must be additional to any activities already taking place'; open code to Additionality principle); while in stage two the open coded statements were axially recoded into summaries (i.e. filtered and sorted into groups of common statements under a summary title such as 'Biodiversity additionality') (two stage process, see Fig. S2). Statement coding in open and axial forms reflected the offset theories (e.g. additionality, no net loss) and/or issues or difficulties raised in the extant or emerging literature (e.g. high risk offsets, offsets timing). The summaries were then used to create a conceptual thematic diagram of the results where the axial summaries were clustered under the node’s major constructs (e.g. policy features, offsets principles) (Miles et al., 2014). Any differences in coding interpretations were resolved through mediating discussions within the research team, including drawing on extant offsets literature (Denzin and Lincoln, 2011).

\subsection{Stakeholders and Data}

A summary of the stakeholder data showed that 56 non-government (47 conservation, education, environment legal services, indigenous and traditional owners; and 9 business, mining, farming and aquaculture) (NGOs), 7 government (political party, city council, regional development agencies, indigenous land and advisory, environment) (GOs), and 5 business (consultants, developers) organisations, with 29 individuals providing written submissions (for stakeholders names and details, 
see Commonwealth of Australia, 2014b). Note, project developers Whitehaven Coal (P1), QGC Pty Ltd (P3) and Jandakot Airport Holdings (P5) provided submission that have been included in the analysis.

A breakdown of the coded data shows that the major concentration of statements were provided by environmental NGOs; the first and second nodes attracted most comments (i.e. greatest issues of interest for stakeholders); and environmental NGOs and GOs provided the highest concentration of statements per stakeholder (see Table 1).

Table 1.

Summary of Stakeholder Statements - Offsets Related Nodes

\begin{tabular}{|c|c|c|c|c|c|c|c|}
\hline \multirow[t]{2}{*}{ Node - Offset Related } & \multicolumn{7}{|c|}{ Number of Statements by Stakeholder Group $(n=742)$} \\
\hline & $\begin{array}{l}\text { Business } \\
\text { Firms }\end{array}$ & $\begin{array}{l}\text { Government } \\
\text { Organizations }\end{array}$ & Individuals & NGO-Business & $\begin{array}{l}\text { NGO-Env. } \\
\text { Conservation }\end{array}$ & $\begin{array}{c}\text { Node } \\
\text { Total } \\
\text { (No.) }\end{array}$ & $\begin{array}{c}\text { Node } \\
\text { Total } \\
(\%)\end{array}$ \\
\hline N1 - Principles and Policy & 8 & $29^{b}$ & 41 & 24 & $162^{\mathrm{a} b}$ & $264^{c}$ & $36 \%$ \\
\hline $\begin{array}{l}\text { N2 - Proposal Development } \\
\text { and Submission }\end{array}$ & $11^{\mathrm{b}}$ & 13 & $45^{b}$ & $25^{b}$ & $147^{\mathrm{a}}$ & 241 & $32 \%$ \\
\hline $\begin{array}{l}\text { N3 - Proposal Assessment } \\
\text { and Approval }\end{array}$ & 1 & 7 & 19 & 5 & $48^{\mathrm{a}}$ & 80 & $11 \%$ \\
\hline $\begin{array}{l}\text { N4 - Monitoring and } \\
\text { Evaluation }\end{array}$ & 4 & 6 & 19 & 7 & $90^{\mathrm{a}}$ & 126 & $17 \%$ \\
\hline N5 - Outcomes and Results & 1 & 4 & 6 & 2 & $18^{\mathrm{a}}$ & 31 & $4 \%$ \\
\hline Stakeholder Total (No.) & 25 & 59 & 130 & 63 & 465 & 742 & \\
\hline Normalized Total (No.) & 5.00 & 8.43 & 4.48 & 7.00 & 9.89 & 7.65 & \\
\hline Stakeholder Total (\%) & $3 \%$ & $8 \%$ & $18 \%$ & $8 \%$ & $63 \%$ & & $100 \%$ \\
\hline
\end{tabular}

\section{Results and Discussion}

A summary of the results is presented in a conceptual thematic diagram using a fully ordered display format and axial summary weightings (Miles et al., 2014) (see Fig. 1). The diagram provides a breakdown of stakeholders' responses by node (1 to 5), sub-node construct (e.g. node 1, Policy Features), axial weighting (\% of responses in sub-node construct) (e.g. $48 \%$ of responses related to Policy Features), and frequency of responses (e.g. node 1, biodiversity net gain had 10 coded responses). The summary show that while environmental NGOs and individuals supported strong offsets policy and enforced programs; business (firms and aligned NGOs) supported the use of direct offsets and OCMs under a federal science based policy, the mitigation hierarchy, and a BBOP-type standard (i.e., principles, criterion, indicators) (BBOP, 2012b). Also, GOs supported a federally 


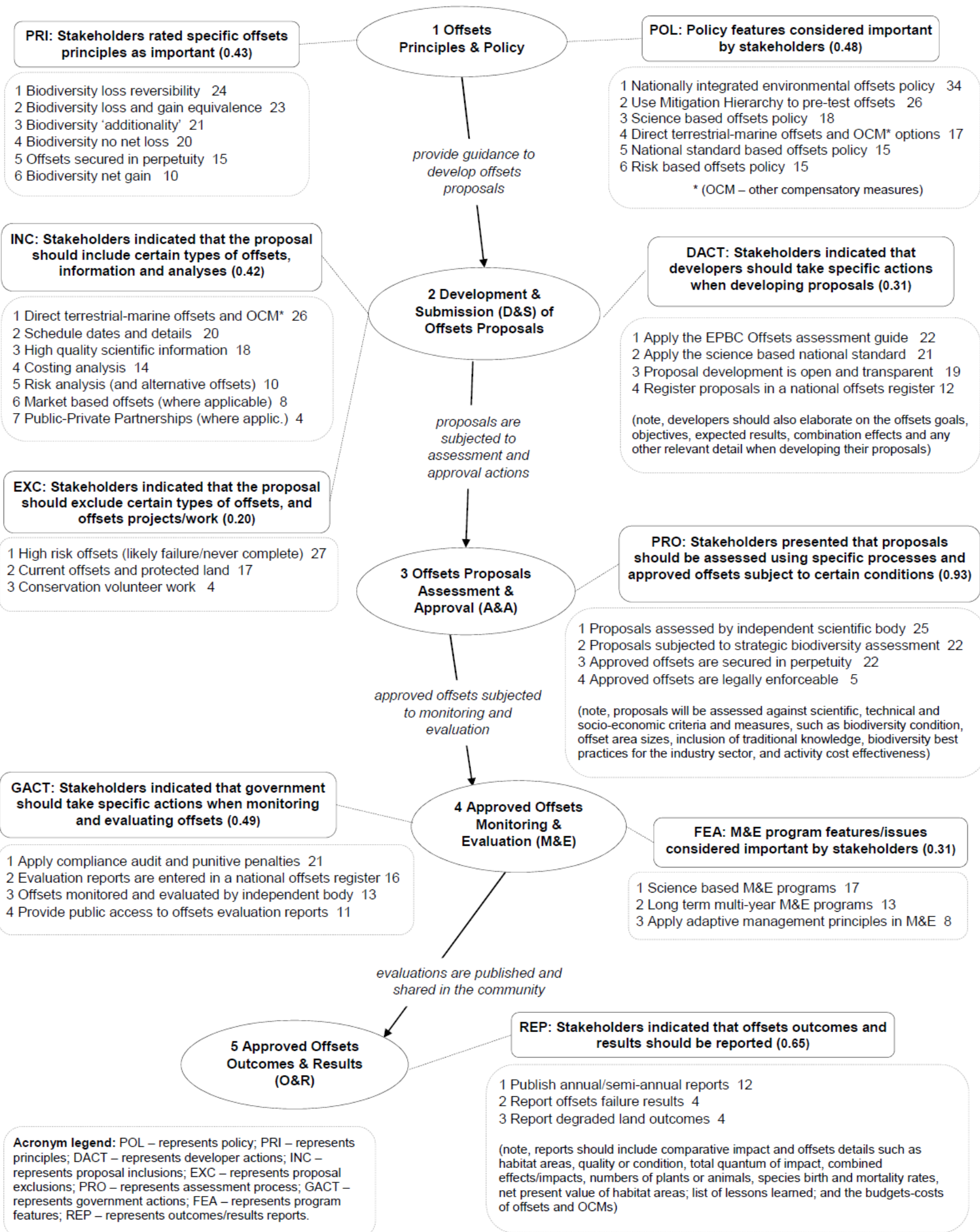

Fig. 1. A conceptual thematic diagram that shows the major themes/issues that came from the coding of stakeholders statements against each node (Table S1 for more detail) (arrows and indicator statements 
show the sequential flow of offsets policy setting to offsets practice as defined under the inquiry) (Miles et al., 2014)

\subsection{Principles and Policy (Node 1)}

The axial summary covered $90 \%$ of statements (i.e. $48 \%$ policy features and $43 \%$ environmental offsets principles) and recommended three major policy adjustments. First, environmental offsets policy consistency was a key priority (POL1, Table S1). Offsets policies at the three governmental tiers would be consistent and harmonized to improve offsets efficacy (McKenney and Kiesecker, 2010). Interpretatively, consistent policy was seen as a mechanism to build complementary offsets programs, composed of direct offsets and OCMs (POL4, Table S1), across government and achieve better outcomes. The federal government is currently streamlining environmental approvals through its “onestop shop” policy, thereby enhancing bilateral agreements and relationships through amendment of the EPBC Act 1999 (Commonwealth of Australia, 2014a).

Second, there was a perception by stakeholders that the mitigation hierarchy was inadequately considered in development decisions, with offsets being favoured in place of avoidance, minimise and rehabilitation/restoration (POL2, Table S1) (Kiesecker et al., 2009; Clare and Krogman, 2013). There was strong sentiment from environmental stakeholders that an assessment should be conducted as part of offsets pre-testing to assure that all environmental impact avoidance, minimization and restoration options have been rigorously canvassed prior to offsets planning:

The mitigation hierarchy should be clearly set out in all relevant planning legislation in each State and Territory as a mandatory pre-condition before any offsetting option is considered. The standard must provide appropriate guidance and emphasis on how a proponent can demonstrate their endeavours to genuinely 'avoid' and 'mitigate' aspects of the proposed development before offsets begin to be considered (Sub. 77, Birdlife Australia, 11 April 2014, p5).

Globally, offsets planning and impact assessment has been positioned as adherent to the mitigation hierarchy (BBOP, 2012b). Under Australian policy, offsets may only compensate for residual impacts after all reasonable measures have been taken to avoid and mitigate impacts on protected matters, including premature consideration of beneficial actions (e.g. offsets) under the EPBC Act 1999 (Macintosh and Waugh, 2014). Third, the introduction of a BBOP-type offsets standard (BBOP, 2012b) (POL5, Table S1), with principles (desired outcomes), criterion (conditions for compliance) and indicators (measures of compliance), was asserted as a means for assuring scientifically based offsets 
(POL3, Table S1) that reflected appropriate levels of offsets risk and uncertainty, and the possibility of offsets project failure (POL6, Table S1) (note, this also reinforces the current Commonwealth policy that requires offsets to be scientifically robust, and account for and manage risks of offsets not succeeding) (Commonwealth of Australia, 2012):

Humane Society International considers that principles governing the use of offsets on which the standard (principles, criterion, indicators) should be based must be as follows - avoidance and mitigation, permanency of the offset, 'like for like'.... (Sub. 28, HSI, 4 April 2014, p1-2).

Following stakeholders' viewpoints, we would argue that having principles, criterion and indicators coupled with developer-oriented and regulator-focused guidelines and protocols; and information management tools and technology (such as web forms, online offsets calculators and assessment guides), could be a critical step for improving offsets outcomes (see Fig. S3). In this schema, the federal government would provide a National Offsets Registry (NOR) database and applications (e.g. registration, management, workflow functions). In addition, we have included an example offsets project data table that could form part of the information management framework (see Table S2).

Stakeholders' stated that inclusion of offsets principles were in large part a reflection of the scientific offsets literature and expert opinion (PRI1-PRI6, Table S1) (see Bull et al., 2013) (note principles PRI1-PRI4 and PRI6 are represented in current Commonwealth policy) (Commonwealth of Australia, 2012). However, the principles are inconsequential unless they can be compliantly translated into successful offsets programs. As an example, the Galilee Coal and Rail project (P2) has approved the clearing of over 8,000 ha of the Brimblebox Nature Refuge (BNR) that was previously protected by the Queensland state government as having exceptional strategic value for increased landscape level biodiversity and environmental conservation (Queensland Government, 2015c). In project approval, the Australian government agreed that the loss of threatened species and ecosystems within the BNR was reversible, could be compensated, and represents NNL to biodiversity. Unfortunately, the environmental offsets strategy presented by Waratah Coal Pty Ltd offers insufficient information to evaluate the likely success of the offsets program (Commonwealth of Australia, 2012). In addition, it should be noted that while we were able to secure some publicly released information on projects 
offsets strategy (see Fig. S1 notes), developers have tended to limit access to offsets data and information.

In addition, it was observed that a key outcome of offsets might be the perpetual (or 'enduring') protection of land and marine estates (i.e. ongoing protection status) as follows:

Offsetting must achieve benefits in perpetuity. An offset area must be legally protected and managed in perpetuity. Offset areas should not be amenable to being offset again in the future (Sub. 60, Australian Network Environmental Defenders Offices, 4 April, 2014, p.4).

This level of protection would require amendments to the EPBC Act 1999 Environmental Offsets Policy (Commonwealth of Australia, 2012, 2014b), and revisions to land management laws. As an example, some protected public land, forests and parks in Australia allow mining and exploration leases to be issued for those tenements (e.g. state forests, reserves, nature refuges, parks) (Queensland Government, 2015c). In the event these land holdings were approved for offsets, a perpetual protection status would need to be legislated, therein prohibiting future development (note the same legal provisions would be required for private land based offsets) (Brownlie and Botha, 2009; Adams and Moon, 2013; Coggan and Whitten, 2013). While possibly difficult to achieve due to economic pressures (Dietz and Adger, 2003), the inclusion of an offsets principle focused on perpetual protection of land and marine estates would be a significant advance for offsets policy, while forcing developers to carefully consider offsets selection and ongoing site management.

\subsection{Offsets Proposals - Development and Submission (Node 2)}

The axial summary covered $93 \%$ of stakeholder statements, with the majority of issues focused on the data and information to be included in the offsets proposal (note, stakeholders also pointed to specific activities that should be excluded from proposals) (INC1-INC7 and EXC1-EXC3, Table S1). Stakeholders considered that proposals should include a composite of direct and market-based (tradeable) offsets, and OCMs for impacted sites and locations (Levrel et al., 2012; Bull et al., 2013; Maron et al., 2013). While current federal offsets policy limits OCMs to a maximum of $10 \%$ of the proposal (see examples, Fig. S1), the scope of proposals is set to expand in the future with some state governments allowing advanced financial settlement of offsets (e.g. Queensland Government Financial Settlement Offsets) (Queensland Government, 2015b). 
Acceptable proposals would also include offsets costing data (program establishment and ongoing delivery and maintenance), schedules and commencement dates (relative to project start-up), and quality and quantity risk analyses, including alternate offsets projects should some fail or only partially succeed (INC2, INC4, INC5, Table S1) (Molainen et al., 2009; Maron et al., 2013). While some of this data is mandated in federal offsets policy (Commonwealth of Australia, 2012), stakeholders advocated for explicit advanced offsets commencement dates where conservation activities predate project startup (land clearing, habitat removal, fauna eviction), thereby contributing to time lag reductions; and, a set of alternate offsets projects (Bekessy et al., 2010; Maron et al. 2012, 2013; Curran et al., 2014). Importantly, these inclusions would be drawn from a national offsets standard, including the supporting planning, design and implementation guidelines, and would be underpinned by suitable evidence, financial guarantees and offsets metrics (BBOP, 2012b).

One of the key issues drawn from the Maules Creek Coal mining project (P1) was the lack of accurate scientific data (INC3, Table S1) on the proposed Critically Endangered Ecological Community (CEEC) offsets:

The Whitehaven Coal's Maules Creek Project in North West NSW highlights the importance of ensuring the adequacy of offsets prior to commencement of the activity. A comprehensive and accurate vegetation mapping exercise prior to approval would have highlighted the deficiencies and militated against approval (Sub 31, National Environmental Law Association, 4 April 2014, p.5).

Informational inaccuracies forced the developer to review and revise the proposal with additional offsets (outlined in developer's submission and response, see notes, Fig. S1). Hence in this example, without quality scientific information, proposed offsets may prove to be deficient and unable to satisfy the biodiversity compensation conditions. While the assessment and approval stage may uncover inaccuracies, we would reinforce that responsibility for the scientific design of offsets should rest with the developer (BBOP, 2012b; Commonwealth of Australia, 2012; Maron et al., 2013). This suggests that developers should exclude all knowingly high risk offsets projects, while also avoiding the inclusion of protected or non-threatened areas (unless conferring the 'perpetual' protection status mentioned earlier) and non-developer funded activities (e.g. volunteer conservation work) in offsets proposals (EXC1-EXC3, Table S1) (Molainen et al., 2009; Burgin, 2011; Gordon et al., 2015). Note, 
the latter two exclusions are referenced in current federal offsets policy (Commonwealth of Australia, 2012).

In developing and submitting proposals, it was also presented by most stakeholder groups that developers should comply with stringent work processes (DACT1-DACT4, Table S1). First, the developers should apply the EPBC Act 1999 federal offsets assessment guide (DACT1, Table S1) (see Fig. S3). The guide was designed to allow developers to create consistent and comparable offsets programs, irrespective of the project type or scope. Second, developers should apply offsets principles, criterion, and indicators that are based on sound environmental science (DACT2, Table S1) (BBOP, 2012b). As noted earlier, this approach would reinforce common and scientifically founded offsetting practices that would also sponsor stakeholder participation and proposal transparency through to final submission (DACT3, Table S1). This collaboration renders opportunities for the integration of administrative, scientific and traditional (local/indigenous) knowledge, with national-level environmental management improvements (Kumaraswamy and Udayakumar, 2011). Noting that stakeholders lamented the lack of a current federal offsets register, developers would lodge their offsets proposal in a publically accessible NOR (DACT4, Table S1) (see Fig. S3):

There is currently no Commonwealth Offsets Register, and no aggregate data for offsets available publicly. Although the Department of Environment holds (paper) records of all Commonwealth offsets, a public register is yet to be developed. The NSWMC supports the development of a public register of offsets. (Sub 76, New South Wales Minerals Council, 13 April 2014, p.5).

This multi-partitioned Database Management System (DBMS) would register offsets proposals, while providing workflow functionality for assessment and approval, monitoring and evaluation, and reporting and publication. As an example, a state-level DBMS implementation in Western Australia displays the type of functionality that might be implemented nationally (for details, see Government of Western Australia, 2015).

\subsection{Offsets Proposals - Assessment and Approval (Node 3)}

The axial summary for assessment and approval of offsets proposals was concentrated in three major areas. Environmental stakeholders asserted that assessments by impartial scientific bodies (such as independent environmental scientists and/or engineers) would provide the best environmental management outcomes for countries engaging in offsets practice (PRO1, Table S1). In essence, this 
type of independent organization would provide expert advisory opinion to the development approval authority (cabinet minister), noting that this practice would tend to obviate claims of potential bias and impropriety, and forms part of global best practice for offsets (BBOP, 2012b; Clare and Krogman, 2013). It was also argued that proposals be assessed using the 'strategic landscape context' principle, rather than on an individual project basis (PRO2, Table S1) (Underwood, 2011; Habib et al., 2013; Quétier et al., 2014). As noted earlier, given that offsets may suffer from the non-cumulative 'project by project' approach (Quétier and Lavorel, 2013), strategic assessment of offsets provides for more rigorous and dispassionate whole of landscape reviews and approvals; thus combining major environmental conservation and biodiversity priorities with the long term view of multiple developments:

As development proposals are predominantly assessed on a project-by-project basis under the EPBC Act, cumulative impacts as a result of multiple development activities are not adequately assessed. To ensure optimal outcomes are achieved, it is essential that cumulative impacts caused by multiple development activities must be considered when determining environmental offsets (Sub. 73 World Wildlife Federation, 11 April 2014, p.2).

In approving offsets, a mix of stakeholders turned to legal instruments in order to secure the perpetual protection of areas, designated as approved offsets in the NOR; and form legally enforceable agreements and contracts that underpin environmental protection (PRO3 and PRO4, Table S1) (Bekessy et al., 2010; Quétier and Lavorel, 2011; Clare and Krogman, 2013). Arguably, environmental and business NGO stakeholders considered that the shift from proposed to approved status should result in a binding legal contract (offsets program) between developers and the federal government.

\subsection{Approved Offsets - Monitoring and Evaluation (Node 4)}

Monitoring and evaluation of approved offsets attracted the third highest volume of stakeholders' statements (see Table 1). The primary issue raised was that offsets delivery agreements must be subjected to strict compliance audit procedures and non-performance (civil) penalties (GACT1, Table S1) as defined in the EPBC Act 1999 - Compliance and Enforcement framework (currently, few project compliance audits are conducted each year, i.e. an average of 6 audits per year during 2006-2014) (Gibbons and Lindenmayer, 2007; Bekessy et al., 2010; Quétier and Lavorel, 2011; Commonwealth of Australia, 2013; Habib et al., 2013). Also, independent third-party auditors and evaluation teams should conduct long term scientific monitoring and evaluation of offsets (GACT3 and FEA2, Table S1 
(minimum length equal to the development project lifecycle) to assure that developers continue to apply the agreed resources (Pickett et al., 2013) and meet the environmental conservation and biodiversity objectives:

The systemic failure of monitoring and compliance activity is arguably a contributing factor in a general absence of a comprehensive, scientific dataset on the impact of offsetting on environmental management. These systemic failures in monitoring and performance mean that biodiversity offset systems will not work without regulatory and institutional reform, in particular an independent, properly-resourced agency responsible for monitoring and compliance (Sub 72, Environment Defenders Office Vic., 10 April 2014, p.6).

In addition, the use of feedback loops and adaptive management principles for monitoring and control would enable the timely management of offsets due to changing environmental background conditions, and the regular update of offsets crediting baselines (FEA1 and FEA3, Table S1) (BBOP, 2012b). In this respect, the revision of offsets programs, particularly the crediting baselines, would go some way to reducing the current practice of setting unrealistic (very steep) baselines that entrench biodiversity loss (Maron et al., 2013, 2015; Gordon et al., 2015). Importantly, monitoring and evaluation reports should be entered into the NOR, therein providing unimpeded public access and transparency (GACT2 and GACT4, Table S1).

\subsection{Approved Offsets - Outcomes and Results (Node 5)}

The outcomes and results node attracted limited comment ( $4 \%$ of all comments), although we concede that the lack of nationally recorded offsets programs that have been in operation for sufficient time periods to generate meaningful outcomes may have resulted in the low response. That said, a crosssection of stakeholders argued that a summary of outcomes and results for all domestic offsets programs should be released annually or semi-annually, including instances of offsets project failures (including the valuable lessons learned by developers) and land degradation (REP1-REP3, Table S1). Critically, these reports would serve a dual purpose, providing an aggregate view of offsets related environmental conservation and biodiversity outcomes, while offering an evolving compendium of 'lessons learned' for the offsets body of knowledge (i.e. understanding how and why offsets measures fail). Reporting functionality could be built into the NOR with a suite of annual and specialist reports and forms configured for production.

\section{Conclusions}


In concluding this article, we acknowledge the limitation that the majority of coded statements were received from stakeholders aligned with the environment and biodiversity, reflecting the need to substantially improve offsets practice and deliver better environmental management outcomes. More statements from project developers and business might have assisted in balancing the discussion and further refining the nexus between development and biodiversity. Nevertheless, the coding and conceptual diagramming exercise provided some directions for improved offsets delivery as follows.

In the area of principles and policy, stakeholder comments asserted that offsets policy should be governmentally consistent; enforce rigorous mitigation hierarchy pretesting of proposed offsets; while founded on good quality science. Importantly, stakeholders also argued for strengthening current policy and creating an associated standard containing operating principles, criterion and indicators (much like those described in BBOP, 2012b) to support sound offsets designs. In addition, enduring protection of offsets sites (no offsetting the offsets), was commended by stakeholders as a key amendment in federal guidelines (principles) (Commonwealth of Australia, 2012).

In developing offsets proposals, stakeholders reinforced the current policy guidelines that call for robust costings, schedule and risk analyses, and accurate scientific survey data (Commonwealth of Australia, 2012), while presenting that developers should be explicitly prohibited from including knowingly high risk offsets in proposals. In addition, employing stringent regulatory and scientific work processes, such as applying a BBOP-type standard for robust proposal development, was asserted an important shift in practice. Stakeholders opined that the government might also assist developers by providing offsets registration and processing infrastructure through a NOR. In sum, these proposed adjustments were aimed at improving offsets development.

Stakeholders also considered that offsets assessment and approval processes required further enhancement. Specifically, having the assessment conducted by independent scientific bodies (not the government); subjecting offsets proposals to a strategic analysis (i.e. considering the cumulative impacts of multiple proposals); and placing enduring protections on approved offsets sites (as per the proposed new principle above) were argued by stakeholders as significant improvements in offsets 
practice. A further improvement offered up by stakeholders (not in current policy) sought a legally enforceable offsets (contract) agreement between the federal government and developers.

In offsets monitoring and evaluation, stakeholders opined that poor offsets administration is unacceptable. Stakeholder parties advocated that the long term scientific monitoring and management of offsets must be open and transparent with a key focus on successful outcomes and compliance. This could be achieved through a well-resourced compliance audit program for offsets, independent evaluations of results and outcomes, and providing public read access to the NOR. To this end, a NOR should provide the technological foundation to manage offsets programs from registration to reporting. Thus, in the reporting context, the NOR could enable annual reporting and publication of offsets programs successes, failures and lessons learned. Hence, in sum, these amendments would support advancement in offsets practice.

In closing, we concede that balancing the priorities for development and biodiversity is already an extremely difficult and complex task. However, if we are to use offsets as an effective environmental management tool, some adjustments in regulatory frameworks and developer practices are presently required. A failure to make these adjustments would render offsets enabled sustainable development more difficult in the future.

\section{Acknowledgements}

The authors kindly acknowledge the assistance provided by the Senate Environment and Communications References Committee staff and access to inquiry data and documentation.

Megan Evans was supported by an Australian Postgraduate Award and a CSIRO Climate Adaptation Flagship scholarship. We also thank the article reviewers and associate editor Dr W De Lange for their instructive comments and revision directives.

\section{Appendix A. Supplementary data}

Supplementary data related to this article can be found at: $<\mathrm{URL}>$

\section{References}

Adams, V., Moon, K., 2013. Security and equity of conservation covenants: Contradictions of private protected area policies in Australia. Land Use Policy 30, 114-119. 
Alvarado-Quesada, I., Hein, L., Weikard, H-P., 2014. Market-based mechanisms for biodiversity conservation: a review of existing schemes and an outline for a global mechanism. Biodivers. Conserv. 23, 1-21.

Bayon, R., Jenkins, M., 2010. The business of biodiversity. Nature 466, 184-185.

BBOP (Business and Biodiversity Offsets Programme), 2012a. Resource Paper: No Net Loss and Loss-Gain Calculations in Biodiversity Offsets. http://bbop.forest-trends.org/guidelines/ Resource_Paper_NNL.pdf

BBOP, 2012b. Standard on Biodiversity Offsets. http://bbop.forest-trends.org/guidelines/Standard.pdf

Bekessy, S., Wintle, B., Lindenmayer, D., McCarthy, M., Colyvan, M., Burgman, M., Possingham, H., 2010. The biodiversity bank cannot be a lending bank. Conserv. Lett. 3, 151-158.

Blignaut, J., Esier, K, de Wit, M, Le Maitre, D, Milton, SJ., Aronson, J., 2013. Establishing the links between economic development and the restoration of natural capital. Current Opin. Env. Sustain. 5: 94-101.

Blignaut, J., Aronson, J., de Groot, R. 2014. Restoration of natural capital: A key strategy on the path to sustainability. Ecol. Eng. 65, 54-61.

Brownlie, S., Botha, M., 2009. Biodiversity offsets: adding to the conservation estate, or 'no net loss'? Impact Assess. and Proj. Appraisal. 27(30), 227-231.

Bull, J., Suttle, K., Gordon, A., Singh, N., Milner-Gulland, E., 2013. Biodiversity offsets in theory and practice. Fauna \& Flora Int. Oryx. 47(3), 369-380.

Bull, J., Milner-Gulland, E., Suttle, K., Singh, N., 2014. Comparing biodiversity offset calculation methods with a case study in Uzbekistan. Biol. Conserv. 178, 2-10.

Burgin, S., 2010. 'Mitigation banks' for wetland conservation: a major success or an unmitigated disaster? Wetlands Ecol. Manage. 18, 49-55.

Burgin, S., 2011. Biodiversity offsets: Lessons from the American experience. Australian Zoologist. 35(3), 544-549.

Clare, S., Krogman, N., 2013. Bureaucratic Slippage and Environmental Offset Policies: The Case of Wetland Management in Alberta. Society \& Nat. Res. 26(6), 672-687.

Coggan, A., Buitelaar, E., Bennett, J., Whitten, S., 2013. Transferable Mitigation of Environmental Impacts of Development: Two Cases of Offsets in Australia, J. Env. Pol. \& Plan, 15(2), 303-322.

Coggan, A., Whitten, S., 2013. Options for flexible biodiversity offset delivery: Location, timing and tenure arrangements. Discussion Paper for the Australia Government Depart of the Environment. CSIRO Ecosystem Sciences, Brisbane.

Commonwealth of Australia., 1992. Intergovernmental Agreement on the Environment (1 May 1992).

Commonwealth of Australia., 2012. Environment Protection and Biodiversity Conservation Act 1999 Environmental Offsets Policy.

Commonwealth of Australia., 2013. Environment Protection and Biodiversity Conservation Act 1999 Compliance and Enforcement Policy.

Commonwealth of Australia, 2014a. Environment Protection and Biodiversity Conservation Amendment (Bilateral Agreement Implementation) Bill 2014.

Commonwealth of Australia, 2014b. Inquiry in Environmental Offsets. http://www.aph.gov.au/ Parliamentary_Business/Committees/Senate/Environment_and_Communications/Environmental_ Offsets

Costanza, R., de Groot, R., Sutton, P., van der Ploeg, S., Anderson, S., Kubiszewski, I., Farber, S., Turner, R., 2014. Changes in the global value of ecosystem services. Global Env. Change. 26, 152-158. 
CSBI (Cross Sector Biodiversity Initiative) (2015). A cross-sector guide for implementing the Mitigation Hierarchy. Biodiversity Consultancy, Cambridge, UK.

Curran, M., Hellweg, S., Beck, J., 2014. Is there any empirical support for biodiversity offset policy? Ecol. Applic. 24(4), 617-632.

Denzin, N., Lincoln, Y., 2011. The Handbook of Qualitative Research 4th Ed. Sage Pub., Thousand Oaks, CA.

Dietz, S, Adger, W., 2003. Economic growth, biodiversity loss and conservation effort. J. Env. Man. 68, 23-35.

Doole, G., Blackmore, L., Schilizzi, S., 2014. Determinants of cost-effectiveness in tender and offset programmes for Australian biodiversity conservation. Land Use Pol. 26, $23-32$.

Gardner, T., Von Hase, A., Brownlie, S., Ekstrom, J., Pilgrim, J., Savy, C., Stephens, R., Treweek, J., Ussher, G., Ward, G., Ten Kate, K., 2013. Biodiversity Offsets and the Challenge of Achieving No Net Loss. Conserv. Biol. 27(6), 1254-1264.

Gibbons, P., Lindenmayer, D. 2007. Offsets for land clearing: No net loss or the tail wagging the dog? Ecol. Man. \& Restor. 8(1), 26-31.

Gordon, A., Bull, J., Wilcox, C., Maron, M., 2015. Perverse incentives risk undermining biodiversity offset policies. J. Appl. Ecol. 52, 532-537

Gordon, A., Langford, W., Todd, J., White, M., Mullerworth, D., Bekessy, S., 2011. Assessing the impacts of biodiversity offset policies. Env. Modelling \& Software. 26, 1481-1488.

Gordon, M., Lockwood, M., Vanclay, F., Hanson, D., Schirmer, J., 2012. Divergent stakeholder views of corporate social responsibility in the Australian forest plantation sector. J. Env. Man. 113, 390-398.

Government of Western Australia, 2015. Environmental Offsets Register. https://offsetsregister.wa.gov.au/public/home/

Habib, T., Farr, D., Schneider, R., Boutin, S., 2013. Economic and Ecological Outcomes of Flexible Biodiversity Offset Systems. Conserv. Biol. 27(6), 1313-1323.

Hassan, R., Scholes, R., Ash, N., 2005. Ecosystems and Human Well-being: Current State and Trends, vol. 1, Findings of the Condition and Trends Working Group of the Millennium Ecosystem Assessment. Island Press, Washington D.C.

Hardner, J., Frumhoff, P., Goetze, D., 2000. Prospects for mitigating carbon, conserving biodiversity, and promoting socioeconomic development objectives through the Clean Development Mechanism. Mitig. and Adapt. Strat. for Global Change. 5, 61-80.

Hayes, N., Morrison-Saunders, A., 2007. Effectiveness of environmental offsets in environmental impact assessment: practitioner perspectives from Western Australia. Impact Assess. and Proj. Appraisal, 25(3), 209-218.

Hegmann, G., Yarranton, G., 2011. Alchemy to reason: Effective use of Cumulative Effects Assessment in resource management. Env. Impact Assess. Rev. 31, 484-490.

IMF (International Monetary Fund), 2015. World Economic Outlook Update. 20 Jan. 2015. http://www.imf.org/external/pubs/ft/weo/2015/update/01/pdf/0115.pdf

Jones, I., Bull, J., Milner-Gulland, E., Esipov, A., Suttle, K., 2014. Quantifying habitat impacts of natural gas infrastructure to facilitate biodiversity offsetting. Ecol. and Evol. 4(1), 79-90.

Kiesecker, J., Copeland, H., Pocewicz, A., Nibbelink, N., Mckenney, B., Dahlke, J., Holloran, M., Stroud, D., 2009. A Framework for Implementing Biodiversity Offsets: Selecting Sites and Determining Scale. BioScience. 59(1), 77-84.

Kumaraswamy, S., Udayakumar, M., 2011. Biodiversity banking: a strategic conservation mechanism. Biodivers. Conserv. 20, 1155-1165. 
Latimer, W., Hill, D., 2007. Mitigation banking: Securing no net loss to biodiversity? A UK perspective. Planning, Prac. \& Res., 22(2), 155-175

Levrel, H., Pioch, S., Spieler, R., 2012. Compensatory mitigation in marine ecosystems: which indicators for assessing the "no net loss" goal of ecosystem services and ecological functions? Marine Pol. 36(6), 1202-1210.

Macintosh, A., Waugh, L., 2014. Compensatory mitigation and screening rules in environmental impact assessment. Env. Imp. Assess. Rev. 49, 1-12.

Maron, M., Bull, J., Evans, M., Gordon, A., 2015. Locking in loss: Baselines of decline in Australian biodiversity offset policies. Biol. Conserv. DOI: http://dx.doi.org/10.1016/j.biocon.2015.05.017.

Maron, M., Dunn, P., McAlpine, C., Apan, A., 2010. Can offsets really compensate for habitat removal? The case of the endangered red-tailed black-cockatoo. J. App. Ecol. 47, 348-355

Maron, M., Hobbs, R., Moilanen, A., Matthews J., Christie, K., Gardner, T., Keith, D., Lindenmayer, D., McAlpine, C., 2012. Faustian bargains? Restoration realities in the context of biodiversity offset policies. Biol. Conserv. 155, 141-148.

Maron, M., Rhodes, J., Gibbons, P., 2013. Calculating the benefit of conservation actions. Conserv. Lett. 6(5), 359-367.

McKenney, B., Kiesecker, J., 2010. Policy Development for Biodiversity Offsets: A Review of Offset Frameworks. Env. Man. 45, 165-176.

Miles, M., Huberman, A., Saldana, J., 2014. Qualitative Data Analysis $3^{\text {rd }}$ Ed. Sage Pub., Thousand Oaks, CA.

Miller, K., Trezise, J., Kraus, S., Dripps, K., Evans, M., Gibbons, P., Possingham, H., Maron, M., 2015. The development of the Australian environmental offsets policy: from theory to practice. Env. Conserv. 42(4), 306-314.

Moilanen, A., van Teeffelen, A., Ben-Haim, Y., Ferrier, S., 2009. How Much Compensation is Enough? A Framework for Incorporating Uncertainty and Time Discounting When Calculating Offset Ratios for Impacted Habitat. Restor. Ecol. 17(4), 470-478.

Morrison-Saunders, A., Pope, J., 2013. Conceptualising and managing trade-offs in sustainability assessment. Env. Impact Assess. Rev. 38, 54-63.

Morrison-Saunders, A., Therivel, R., 2006. Sustainability integration and assessment. J. Env. Assess. Pol. and Man. 8(3), 281-298.

Norton, D., 2009. Biodiversity Offsets: Two New Zealand Case Studies and an Assessment Framework. Env. Man. 43, 698-706.

Overton, J., Stephens, R., Ferrier, S., 2013. Net Present Biodiversity Value and the Design of Biodiversity Offsets. AMBIO 4, 100-110.

Pickett, E., Stockwell, M., Bower, D., Garnham, J., Pollard, C., Clulow, J., Mahony, M., 2013. Achieving no net loss in habitat offset of a threatened frog required high offset ratio and intensive monitoring. Biol. Conserv. 157, 156-162.

Queensland Government 2015a. Environmental Legislation. http://www.ehp.qld.gov.au/ management/non-mining/environmental-legislation.html

Queensland Government, 2015b. Financial settlement offset calculator. https://environment. ehp.qld.gov.au/ offsets-calculator/?calculate=financial

Queensland Government, 2015c. The Nature Refuges Program. http://www.ehp.qld.gov.au/ ecosystems/nature-refuges/the_nature_refuges_program.html

Quétier, F., Regnery, B., Levrel, H., 2014. No net loss of biodiversity or paper offsets? A critical review of the French no net loss policy. Env. Sci. \& Pol. 38, 120-131. 
Quétier, F., Lavorel. S., 2013. Assessing ecological equivalence in biodiversity offset schemes: Key issues and solutions. Biol. Conserv. 144, 2991-2999.

Quintero, J., Mathur, A., 2011. Biodiversity Offsets and Infrastructure. Conserv. Biol. 25(6), 11211123.

Rajvanshi, A., Brownlie, S., Slootweg, R., Arora, R., 2011. Maximizing benefits for biodiversity: the potential of enhancement strategies in impact assessment. Impact Assess. and Proj. Appraisal, 29(3), 181-193.

Regnery, B., Couvet, D., Kerbiriou, C., 2013. Offsets and Conservation of the Species of the EU Habitats and Birds Directives. Conserv Biol. 27(6), 1335-1343.

Reid, C., 2011. The Privatisation of Biodiversity? Possible New Approaches to Nature Conservation Law in the UK. J. Env. Law 23:2, 203-231.

Ruhl, J., Salzman, J., 2011. Gaming the past: The theory and practice of administrative baselines in the administrative state. Vand. L. Rev. 64(1), 1-24.

Sherren, K., Yoon, H-J., Clayton, H., Schirmer, J., 2012. Do Australian graziers have an offset mindset about their farm trees? Biodivers. Conserv. 21, 363-383.

Underwood, J., 2011. Combining landscape-level conservation planning and biodiversity offset programs: a case study. Env. Man. 47, 121-129.

Virah-Sawmy, M., Ebeling, J., Taplin, R., 2014. Mining and biodiversity offsets: A transparent and science-based approach to measure "no-net-loss”. J. Env. Man. 143, 61-70.

Walker, S., Brower, A., Stephens, R., Lee, W., 2009. Why bartering biodiversity fails. Conserv. Lett. 2, 149-157. 


\title{
SUPPLEMENTARY MATERIAL
}

\section{USING OFFSETS TO MITIGATE ENVIRONMENTAL IMPACTS OF \\ MAJOR PROJECTS: A STAKEHOLDER ANALYSIS}

\author{
Nigel Martin*, The Australian National University \\ Megan Evans, The Australian National University \\ John Rice, The University of New England \\ Sumit Lodhia, The University of South Australia \\ Philip Gibbons, The Australian National University \\ *Corresponding author. Tel: +61-2-61259793; Fax: +61-2-61259982 \\ E-mail address: nigel.martin@anu.edu.au
}

Tables: 2

Figures: 3

Pages: 6 
Table S1. Summary of Stakeholder Group Responses - Offsets Related Nodes and Issues

\begin{tabular}{|c|c|c|c|c|c|c|c|c|c|c|}
\hline \multirow{3}{*}{ Node / Issue } & \multicolumn{10}{|c|}{$\begin{array}{c}\text { Stakeholder Group Response } \\
\text { (Number and Percentage of Coded Statements) }\end{array}$} \\
\hline & \multicolumn{2}{|c|}{$\begin{array}{l}\text { Business } \\
\text { Firms }\end{array}$} & \multicolumn{2}{|c|}{ Govt. Org. } & \multicolumn{2}{|c|}{ Individuals } & \multicolumn{2}{|c|}{$\begin{array}{l}\text { NGO } \\
\text { Business }\end{array}$} & \multicolumn{2}{|c|}{$\begin{array}{l}\text { NGO Env. } \\
\text { Conservation }\end{array}$} \\
\hline & No. & $\%$ & No. & $\%$ & No. & $\%$ & No. & $\%$ & No. & $\%$ \\
\hline N1: POL1 Federally consistent environmental offsets policy & - & - & 9 & 26 & 2 & 6 & 7 & 21 & 16 & 47 \\
\hline N1: POL2 Use Mitigation Hierarchy to pre-test offsets & 1 & 4 & 2 & 8 & 1 & 4 & 5 & 19 & 17 & 65 \\
\hline N1: POL3 Science based offsets policy & - & - & 2 & 11 & 1 & 6 & 3 & 17 & 12 & 66 \\
\hline N1: POL4 Direct terrestrial-marine offsets and OCM & 1 & 6 & 3 & 18 & 2 & 12 & - & - & 11 & 66 \\
\hline N1: POL5 Offsets policy based on principles, criterion, indicators & 1 & 7 & 1 & 7 & 2 & 13 & 3 & 20 & 8 & 53 \\
\hline N1: POL6 Risk based offsets policy & 1 & 7 & 2 & 13 & 3 & 20 & - & - & 9 & 53 \\
\hline N1: PRI1 Biodiversity loss reversibility & - & - & 1 & 4 & 5 & 21 & 1 & 4 & 17 & 71 \\
\hline N1: PRI2 Biodiversity loss and gain equivalence & - & - & 2 & 9 & 5 & 26 & - & - & 15 & 65 \\
\hline N1: PRI3 Biodiversity ‘additionality’ & 1 & 5 & 3 & 14 & 4 & 19 & - & - & 13 & 62 \\
\hline N1: PRI4 Biodiversity no net loss & 1 & 5 & - & - & 6 & 30 & 1 & 5 & 12 & 60 \\
\hline N1: PRI5 Offsets secured in perpetuity & 1 & 7 & 1 & 7 & 2 & 13 & - & - & 11 & 73 \\
\hline N2: DACT1 Apply the EPBC Offsets assessment guide & 2 & 9 & 1 & 5 & 5 & 23 & 2 & 9 & 12 & 54 \\
\hline N2: DACT2 Apply science based principles, criteria, indicators & 2 & 10 & - & - & 3 & 14 & 5 & 24 & 11 & 52 \\
\hline N2: DACT3 Proposal development is open and transparent & 1 & 5 & 1 & 5 & 3 & 16 & 1 & 5 & 13 & 69 \\
\hline N2: DACT4 Register proposals in a national offsets register & - & - & - & - & 2 & 17 & 1 & 8 & 9 & 75 \\
\hline N2: INC1 Direct terrestrial-marine offsets and OCM (include) & 3 & 12 & 3 & 12 & 3 & 12 & 4 & 15 & 13 & 49 \\
\hline N2: INC2 Schedule dates and details (include) & - & - & - & - & 3 & 15 & 1 & 5 & 16 & 80 \\
\hline N2: INC3 High quality scientific information (include) & 1 & 6 & - & - & 7 & 39 & - & - & 10 & 55 \\
\hline N2: INC4 Costing analysis (include) & - & - & - & - & 2 & 14 & 1 & 7 & 11 & 79 \\
\hline N2: INC5 Risk analysis (and alternative offsets) (include) & - & - & - & - & 2 & 20 & - & - & 8 & 80 \\
\hline N2: INC6 Market based offsets (where applicable) (include) & 1 & 13 & - & - & 2 & 26 & 1 & 13 & 4 & 48 \\
\hline N2: INC7 Public-Private Partnerships (where applicable) (include) & - & - & 1 & 25 & - & - & 1 & 25 & 2 & 50 \\
\hline N2: EXC1 High risk offsets (likely failure/incomplete) (exclude) & 1 & 4 & - & - & 6 & 22 & 1 & 4 & 19 & 70 \\
\hline N2: EXC2 Current offsets and protected land (exclude) & - & - & - & - & 3 & 18 & - & - & 14 & 82 \\
\hline N2: EXC3 Conservation volunteer work (exclude) & - & - & - & - & 1 & 25 & - & - & 3 & 75 \\
\hline N3: PRO1 Proposals assessed by independent scientific body & - & - & 3 & 8 & 6 & 24 & - & - & 16 & 68 \\
\hline N3: PRO2 Proposals subjected to strategic biodiversity assessment & 1 & 5 & 1 & 5 & 5 & 23 & 2 & 9 & 13 & 58 \\
\hline N4: GACT2 Eval. reports are entered in a national offsets register & - & - & - & - & 3 & 19 & 2 & 13 & 11 & 68 \\
\hline N4: GACT3 Offsets monitored and evaluated by independent body & - & - & 1 & 8 & 3 & 23 & - & - & 9 & 69 \\
\hline N4: GACT4 Public access to offsets evaluation reports & - & - & - & - & - & - & - & - & 11 & 100 \\
\hline N4: FEA1 Science based M\&E programs & 1 & 6 & - & - & 3 & 18 & 2 & 12 & 11 & 64 \\
\hline N4: FEA2 Long term multi-year M\&E programs & 1 & 8 & 1 & 8 & 4 & 31 & - & - & 7 & 57 \\
\hline N4: FEA3 Apply adaptive management principles in M\&E & - & - & - & - & 1 & 13 & - & - & 7 & 87 \\
\hline N5: REP1 Publish annual/semi-annual reports & 1 & 8 & 1 & 8 & 1 & 8 & 1 & 8 & 8 & 68 \\
\hline N5: REP2 Report offsets failure results & - & - & - & - & 1 & 25 & - & - & 3 & 75 \\
\hline N5: REP3 Report degraded land outcomes & - & - & 2 & 50 & 1 & 25 & - & - & 1 & 25 \\
\hline
\end{tabular}

Note: OCM = Other compensatory measures. Colour Coded Stakeholder Summary:

\begin{tabular}{|l|l|}
\hline Business Firms $(\mathrm{n}=5)$ & \\
\hline GO $(\mathrm{n}=7)$ & \\
\hline Individuals $(\mathrm{n}=29)$ & \\
\hline NGO - Business $(\mathrm{n}=9)$ & \\
\hline NGO - Env. Conservation $(\mathrm{n}=47)$ & \\
\hline
\end{tabular}


Table S2. Project 2 (P2): Waratah Coal Pty Ltd - Galilee Coal and Rail Project - Offsets Data Table (Example)

\begin{tabular}{|c|c|c|c|c|}
\hline Serial & Goal $^{\mathrm{a}}$ & Activities ${ }^{b}$ & Est. Cost ${ }^{\mathrm{C}}$ & Expected Results $^{\mathrm{d}}$ \\
\hline 1 & $\begin{array}{l}\text { To compensate for } \\
\text { authorised unavoidable } \\
\text { impacts on (Avian) } \\
\text { MNES - Black } \\
\text { Throated Finch } \\
\end{array}$ & $\begin{array}{l}\text { 10,000 hectares (Primary } \\
\text { Habitat) - grassy open forested } \\
\text { habitats: acquire/secure, restore } \\
\text { and maintain }\end{array}$ & $\mathrm{A} \$ 20.18 \mathrm{~m}$ & $\begin{array}{l}\text { Good condition remnant and mature } \\
\text { regrowth vegetation - Brigalow } \\
\text { (Acacia harpophylla); Increase } \\
\text { habitat valuation; Increase birth rate } \\
\text { \& total no.; Reduce pop. mortality }\end{array}$ \\
\hline 2 & $\begin{array}{l}\text { To compensate for } \\
\text { authorised unavoidable } \\
\text { impacts on (Avian) } \\
\text { MNES - Squatter } \\
\text { Pigeon }\end{array}$ & $\begin{array}{l}\text { 6,000 hectares (Primary } \\
\text { Habitat) - dry grassy eucalypt } \\
\text { woodlands and open forests in } \\
\text { sandy country: acquire/secure, } \\
\text { restore and maintain }\end{array}$ & $\mathrm{A} \$ 12.11 \mathrm{~m}$ & $\begin{array}{l}\text { Good condition remnant and mature } \\
\text { regrowth vegetation - Brigalow } \\
\text { (Acacia harpophylla); Increase } \\
\text { habitat valuation; Increase birth rate } \\
\text { \& total no.; Reduce pop. mortality }\end{array}$ \\
\hline 3 & $\begin{array}{l}\text { To compensate for } \\
\text { authorised unavoidable } \\
\text { impacts on (Avian) } \\
\text { MNES - Red Goshawk }\end{array}$ & $\begin{array}{l}383 \text { hectares Primary Habitat - } \\
\text { tall open forest, woodland, } \\
\text { lightly treed savannah: } \\
\text { acquire/secure, restore and } \\
\text { maintain }\end{array}$ & $\mathrm{A} \$ 0.78 \mathrm{~m}$ & $\begin{array}{l}\text { Good condition remnant and mature } \\
\text { regrowth vegetation - Brigalow } \\
\text { (Acacia harpophylla); Increase } \\
\text { habitat valuation; Increase birth rate } \\
\text { \& total no.; Reduce pop. mortality }\end{array}$ \\
\hline 4 & $\begin{array}{l}\text { To compensate for } \\
\text { authorised unavoidable } \\
\text { impacts on } \\
\text { (Mammalian) MNES - } \\
\text { Northern Quoll } \\
\end{array}$ & $\begin{array}{l}500 \text { hectares Primary Habitat - } \\
\text { rocky ranges, open eucalypt } \\
\text { forests: acquire, restore and } \\
\text { maintain }\end{array}$ & $\mathrm{A} \$ 1.01 \mathrm{~m}$ & $\begin{array}{l}\text { Good condition remnant and mature } \\
\text { regrowth vegetation - Brigalow } \\
\text { (Acacia harpophylla); Increase } \\
\text { habitat valuation; Increase birth rate } \\
\text { \& total no.; Reduce pop. mortality }\end{array}$ \\
\hline 5 & $\begin{array}{l}\text { To compensate for } \\
\text { authorised unavoidable } \\
\text { impacts on (Reptilian) } \\
\text { MNES - Yakka Skink }\end{array}$ & $\begin{array}{l}5,800 \text { hectares Primary Habitat } \\
\text { - rocky outcrops, sand plain } \\
\text { areas and dense ground } \\
\text { vegetation, in association with } \\
\text { open ironbark or woodland, } \\
\text { Brigalow forest and open shrub } \\
\text { land: acquire/secure, restore } \\
\text { and maintain }\end{array}$ & $\mathrm{A} \$ 11.71 \mathrm{~m}$ & $\begin{array}{l}\text { Good condition remnant and mature } \\
\text { regrowth vegetation - Brigalow } \\
\text { (Acacia harpophylla); Increase } \\
\text { habitat valuation; Increase birth rate } \\
\text { \& total no.; Reduce pop. mortality }\end{array}$ \\
\hline 6 & $\begin{array}{l}\text { To compensate for } \\
\text { authorised unavoidable } \\
\text { impacts on (Reptilian) } \\
\text { MNES - Ornamental } \\
\text { snake }\end{array}$ & $\begin{array}{l}270 \text { hectares Primary Habitat - } \\
\text { vegetation of woodland and } \\
\text { shrub land, including some } \\
\text { Briglaow Acacia harpophylla, } \\
\text { and open forest: acquire/secure, } \\
\text { restore and maintain }\end{array}$ & $\mathrm{A} \$ 0.55 \mathrm{~m}$ & $\begin{array}{l}\text { Good condition remnant and mature } \\
\text { regrowth vegetation - Brigalow } \\
\text { (Acacia harpophylla); Increase } \\
\text { habitat valuation; Increase birth rate } \\
\text { \& total no.; Reduce pop. mortality }\end{array}$ \\
\hline 7 & $\begin{array}{l}\text { To compensate for } \\
\text { authorised unavoidable } \\
\text { impacts on (Reptilian) } \\
\text { MNES - Dunmall’s } \\
\text { snake }\end{array}$ & $\begin{array}{l}72 \text { hectares Primary Habitat - } \\
\text { Open forest and woodland, } \\
\text { particularly Brigalow Acacia } \\
\text { harpophylla forest and } \\
\text { woodland: acquire/secure, } \\
\text { restore and maintain }\end{array}$ & $\mathrm{A} \$ 0.15 \mathrm{~m}$ & $\begin{array}{l}\text { Good condition remnant and mature } \\
\text { regrowth vegetation - Brigalow } \\
\text { (Acacia harpophylla); Increase } \\
\text { habitat valuation; Increase birth rate } \\
\text { \& total no.; Reduce pop. mortality }\end{array}$ \\
\hline 8 & $\begin{array}{l}\text { To compensate for } \\
\text { authorised unavoidable } \\
\text { impacts on Threatened } \\
\text { Ecological Community } \\
\text { - Brigalow (Acacia } \\
\text { harpophylla dominant } \\
\text { and co-dominant) }\end{array}$ & $\begin{array}{l}199 \text { hectares Primary Habitat - } \\
\text { Brigalow (Acacia harpophylla): } \\
\text { acquire/secure, restore and } \\
\text { maintain }\end{array}$ & $\mathrm{A} \$ 0.41 \mathrm{~m}$ & $\begin{array}{l}\text { Good condition remnant and mature } \\
\text { regrowth vegetation - Brigalow } \\
\text { (Acacia harpophylla); Increase } \\
\text { habitat valuation; Increase total no. } \\
\text { habitat trees and features }\end{array}$ \\
\hline
\end{tabular}

Notes: ${ }^{\text {a }}$ EPBC2009/4737 Approval (19 December 2013). ${ }^{\text {b }}$ EPBC2009/4737 Approval (19 December 2013).

${ }^{c}$ Estimate based on: Herron Todd White - Australian Grazing Property Index - National Update 27 February 2014, Broad acre scrubby land median purchase prices Central/North Queensland (A $\$ 1,050$ per ha). Schirmer, J., Field, J., 2000. The Cost of Revegetation. Report for Greening Australia. ANU School of Forestry. Used benchmark A $\$ 968$ per hectare cost of natural assisted regeneration in warm, moist region, (original estimate indexed for $3 \%$ inflation per year between 2000-2016). Estimate only includes acquire and restore habitat to good condition. Habitat maintenance will require additional funding. ${ }^{\mathrm{d}}$ Galilee Coal Project EIS Biodiversity Offset Strategy, Report No. WAR005-ENV-RPT-0001, Unidel (17 June 2011); Commonwealth of Australia., 2012. Environment Protection and Biodiversity Conservation Act 1999 Environmental Offsets Assessment Guide. 


\begin{tabular}{|c|c|c|c|}
\hline \multirow[b]{3}{*}{ 兽 } & \multicolumn{3}{|c|}{ PROJECT CHAIN OF COMPENSATION } \\
\hline & Project Scope/Conditions & Stated Project Impacts & Proposed Offsets/Strategy \\
\hline & $\begin{array}{l}\text { Project } 1 \text { (P1): Whitehaven Coal and } \\
\text { Boggabri Coal joint venture - Maules } \\
\text { Creek Coal Mining Project, Boggabri } \\
\text { New South Wales (open cut mine and } \\
\text { railway operations). } \\
\text { Offsets Conditions: EPBC threatened } \\
\text { species 14,866 ha; A } \$ 61 \text { million } \\
\text { funding. }\end{array}$ & $\begin{array}{l}\text { Land Clearing: White Box-Yellow } \\
\text { Box-Blakely's Red Gum Grassy } \\
\text { Woodland and Derived Native Grassland } \\
\text { Critically Endangered Ecological } \\
\text { Community (CEEC) (2,179 ha). } \\
\text { Species Impacts: Foraging Habitat (FH) } \\
\text { - Regent Honeyeater, Swift Parrot and } \\
\text { South-eastern Long-eared Bat. }\end{array}$ & $\begin{array}{l}\text { Direct Offsets: Habitat conservation in } 15 \\
\text { proximate properties surrounding the mine } \\
\text { site: (i) CEEC: Derived Native Grassland } \\
\text { 1,875 ha, and Box Gum Grassy Woodland } \\
\text { 3,828 ha. (ii) FH: Good condition vegetation } \\
\text { 4,974 ha, and Low to moderate condition } \\
\text { vegetation 4,469 ha. }\end{array}$ \\
\hline 春 & $\begin{array}{l}\text { Project } 2 \text { (P2): Waratah Coal Pty Ltd } \\
\text { - Galilee Coal and Rail Project, } \\
\text { Galilee Basin, Queensland (two open } \\
\text { cut and four underground mines and a } \\
\text { railway line) } \\
\text { Offsets Conditions: EPBC threatened } \\
\text { species 23,224 ha; A } \$ 1 \text { million } \\
\text { funding. }\end{array}$ & $\begin{array}{l}\text { Land Clearing: Regional Ecosystems } \\
\text { (RE), Essential Habitats (EH), Protected } \\
\text { Areas (PA) (9,117 ha). } \\
\text { Species Impacts: FH - various migratory } \\
\text { bird species, endangered Black-throated } \\
\text { Finch and Northern Quoll; four } \\
\text { vulnerable lizard species (Ornamental } \\
\text { Snake, Striped Tailed Delma, Yakka } \\
\text { Skink, Brigalow Scaly-foot) (10,601 ha). }\end{array}$ & $\begin{array}{l}\text { Direct Offsets: (i) Habitat conservation in } \\
\text { multiple properties within } 50 \text { and } 100 \mathrm{~km} \text { of } \\
\text { the mine-railway: Good condition remnant } \\
\text { and mature regrowth vegetation } 17,269 \text { ha. } \\
\text { (ii) Habitat conservation in multiple } \\
\text { proximate properties in Queensland: (a) Good } \\
\text { condition remnant and mature regrowth } \\
\text { vegetation } 354 \text { ha. (b) FH: Good condition } \\
\text { remnant and mature regrowth vegetation } \\
10,601 \text { ha. }\end{array}$ \\
\hline 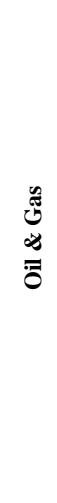 & $\begin{array}{l}\text { Project } 3 \text { (P3): QGC Pty Ltd - Curtis } \\
\text { LNG Project (development of Gas } \\
\text { Fields in south-central Queensland } \\
\text { (Surat Basin), an LNG Facility on } \\
\text { Curtis Island (Gladstone), and } \\
\text { pipelines construction. } \\
\text { Offsets Conditions: Habitat } \\
\text { conservation 3,541 ha; A } \$ 25 \text { million } \\
\text { funding. }\end{array}$ & $\begin{array}{l}\text { Land Clearing: Remnant vegetation and } \\
\text { regrowth Acacia woodlands (9,577 ha) } \\
\text { and Blue Gum woodlands (40 ha). } \\
\text { Species Impacts: FH and nesting habitat } \\
\text { - vulnerable Powerful Owl, Beach Stone } \\
\text { Curlew, Eastern Curlew, Squatter Pigeon } \\
\text { (Curtis Island), and habitat - } \\
\text { endangered/vulnerable species - Tusked } \\
\text { Frog, Collared Delma, Brigalow Scaly- } \\
\text { foot, Yakka Skink, Short-Necked Worm- } \\
\text { Skink, Ornamental Snake, Dunmall’s } \\
\text { Snake, Grey Snake, Yellow-naped Snake } \\
\text { and Northern Quoll (Gas Fields and } \\
\text { pipeline) }\end{array}$ & $\begin{array}{l}\text { Direct Offsets: (i) Habitat conservation } \\
\text { Curtis Island Environmental Management } \\
\text { Precinct 4,500ha. Good condition vegetation } \\
\text { communities and RE. Nesting sites for } \\
\text { Flatback sea turtles and Yellow-breasted Chat } \\
\text { Birds. (ii) Curtis Island World Heritage Area } \\
\text { environmentally significant land 25,000ha. } \\
\text { (iii) Conservation Investment: Impact of gas } \\
\text { field to be offset with equivalent good } \\
\text { condition vegetation communities and habitat } \\
2,100 \text { ha. } \\
\text { Other compensatory measures (OCM): } \\
\text { Payments of A\$11 million over } 20 \text { years to } \\
\text { Great Barrier Reef Marine Park Authority. }\end{array}$ \\
\hline 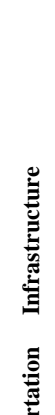 & $\begin{array}{l}\text { Project } 4 \text { (P4): North Queensland } \\
\text { Bulk Ports - Abbot Point Coal } \\
\text { Terminal Capital Dredging Project } \\
\text { (dredge approx. three million cubic } \\
\text { metres from the seabed around six } \\
\text { new ship berths in port exclusion } \\
\text { zone) } \\
\text { Offsets Conditions: Turtle } \\
\text { Plan/Marine Plan (part of Marine } \\
\text { offset strategy); A } \$ 18 \text { million } \\
\text { funding. }\end{array}$ & $\begin{array}{l}\text { Non-residual Impacts: (i) Dredge } \\
\text { footprint and adjacent seagrass } \\
\text { disturbance (up to } 185 \text { ha) up to three } \\
\text { years. (ii) Increased water turbidity at } \\
\text { dredge and disposal sites up to several } \\
\text { weeks. }\end{array}$ & $\begin{array}{l}\text { Direct Offsets: (i) Installation of seagrass } \\
\text { friendly screw moorings in areas currently } \\
\text { impacted by anchors. Support seagrass } \\
\text { recovery. (ii) Development and } \\
\text { implementation of a Water Quality } \\
\text { Improvement Plan (WQIP) for the Don River } \\
\text { catchment as part of the Burdekin Catchment } \\
\text { Natural Resources Management Plan. }\end{array}$ \\
\hline $\begin{array}{l}\text { क्ञे } \\
\text { है }\end{array}$ & $\begin{array}{l}\text { Project } 5 \text { (P5): Jandakot Airport } \\
\text { Holdings - Airport Developments } \\
\text { Offsets Conditions: EPBC threatened } \\
\text { species 1,600 ha; A } \$ 9.2 \text { million rehab. } \\
\text { funding; A } \$ 0.75 \text { million research } \\
\text { funding }\end{array}$ & $\begin{array}{l}\text { Land Clearing: Very good-excellent } \\
\text { condition Native vegetation and Banksia } \\
\text { species (167 ha). } \\
\text { Species Impacts: FH - threatened } \\
\text { Carnaby's (Black) Cockatoo. }\end{array}$ & $\begin{array}{l}\text { Direct Offsets: Habitat conservation: FH - } \\
\text { Carnaby's Cockatoo near Gingin (Moore } \\
\text { River National Park proximity), for } \\
\text { protection/addition to the conservation estate } \\
1,600 \text { ha. }\end{array}$ \\
\hline & cincts 6 and 6 A, StratGen Pty Ltc & Environment Report Supplementary & $\begin{array}{l}\text { PBC 2010/5566, Report No. 1308001RP3, } \\
\text { 3) (P2) Galilee Coal Project EIS Biodiversity } \\
37 \text { Approval (19 December 2013) (P3). QGC } \\
\text { Imunity Committee Meeting Minutes (Offsets } \\
\text { tober 2010) (P4) Abbot Point, Terminal 0, } \\
\text { ort (EPBC 2011/6213/GBRMPA G34897.1), } \\
\text { (P5) Jandakot Airport Holdings EPBC Act } \\
\text { 14). }\end{array}$ \\
\hline
\end{tabular}

Figure S1. Australian infrastructure projects with environmental impacts and offsets 


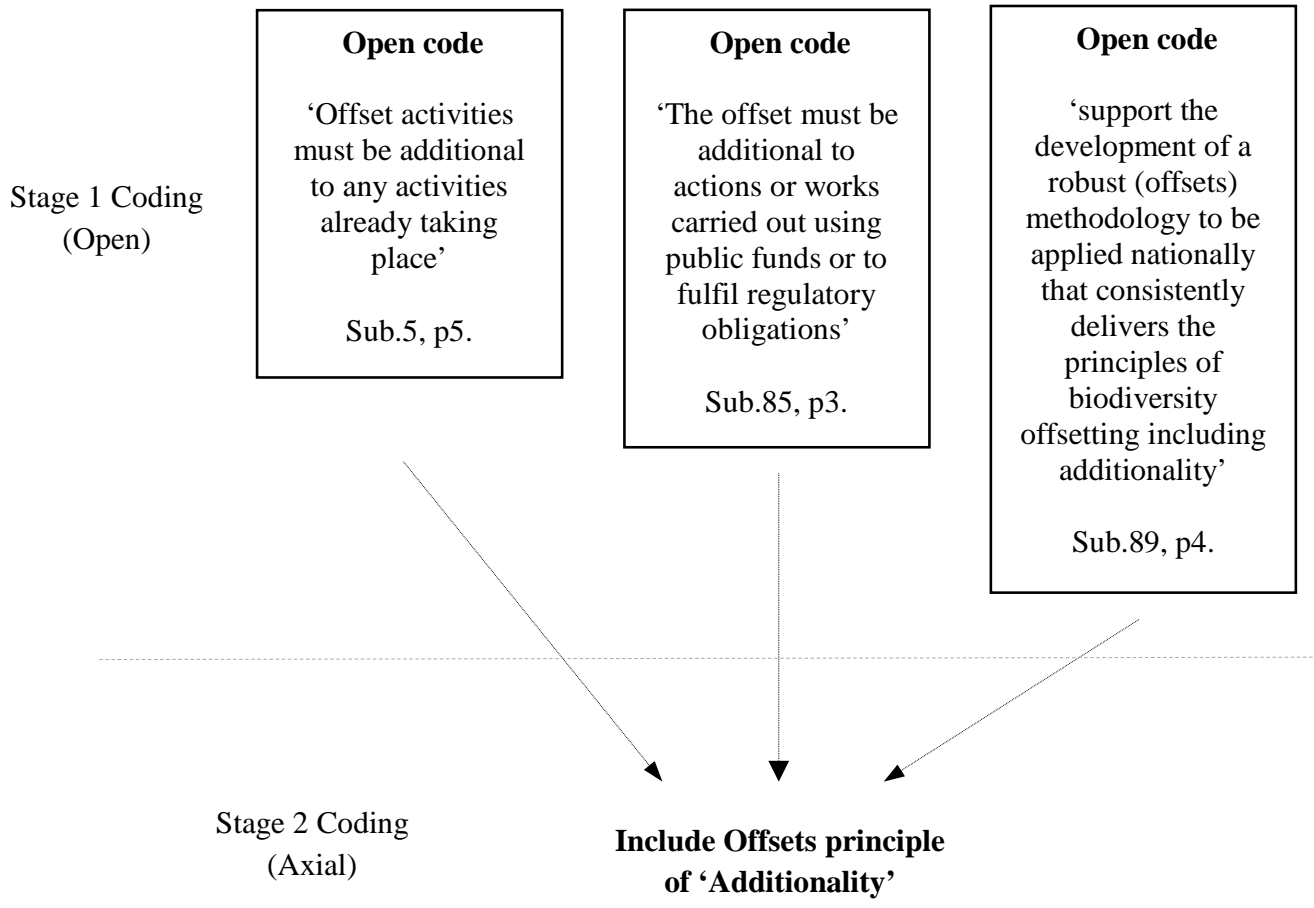

\section{Axial (summary) code}

'Offset activities must be additional to any activities already taking place' Sub.5, p5.

'The offset must be additional to actions or works carried out using public funds or to fulfil regulatory obligations' Sub.85, p3.

'support the development of a robust (offsets) methodology to be applied nationally that consistently delivers the principles of biodiversity offsetting including additionality’ Sub.89, p4.

Figure S2. Example of open code and axial (summary) code processing arrangements 


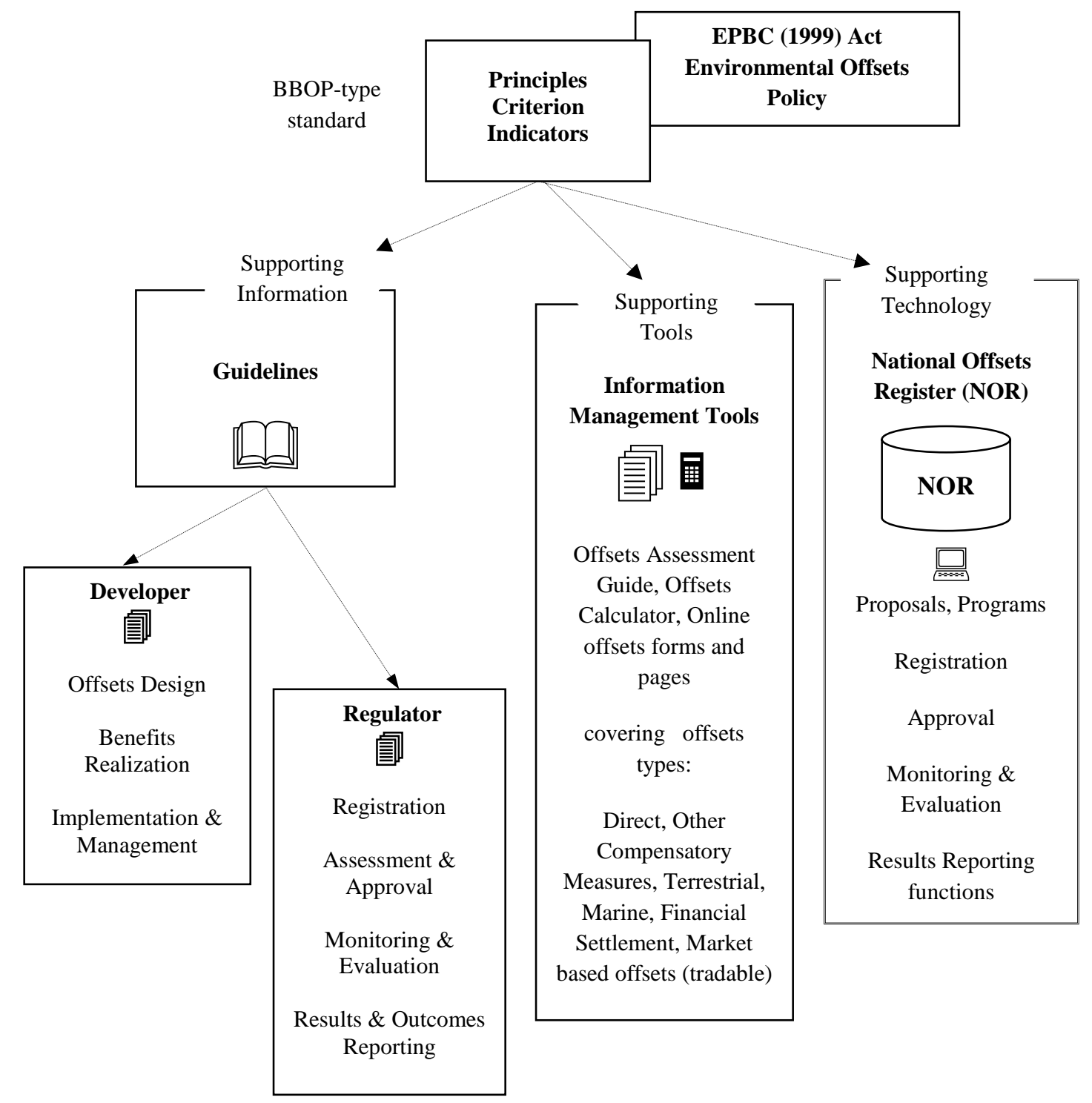

Figure S3. BBOP-type offsets standard - Sample Schema 